\title{
THE DENDROCHRONOLOGY OF PINUS ELLIOTTII IN THE LOWER FLORIDA KEYS: CHRONOLOGY DEVELOPMENT AND CLIMATE RESPONSE
}

\author{
GRANT L. HARLEY*, HENRI D. GRISSINO-MAYER, and SALLY P. HORN \\ Laboratory of Tree-Ring Science, Initiative for Quaternary Paleoclimate Research, Department of Geography, The \\ University of Tennessee, Knoxville, TN 37996-0925, USA
}

\begin{abstract}
South Florida slash pine (Pinus elliottii var. densa) is the southernmost pine species in the United States and the foundation species of the globally endangered pine rockland communities in south Florida. To test if slash pine produces annual growth rings in the Lower Florida Keys, we counted the number of rings on samples collected from the North Big Pine Key site (NBP), which contained a fire scar from a known wildfire and a known date for hurricane-induced tree mortality (2006 or 2007). In addition, a crossdated tree-ring chronology (1871-2009) was developed from living trees and remnant wood found at the site and compared to divisional climate data to determine how the regional climate regime influences radial growth. Our analyses demonstrated that slash pine forms anatomically distinct, annual growth rings with the consistent year-to-year variability necessary for rigorous dendrochronological studies. Response-function and correlation analysis showed that annual growth of slash pine at NBP is primarily influenced by water availability during the growing season. However, no significant correlations were found between tree growth and the Atlantic Multidecadal Oscillation or the El Niño-Southern Oscillation. Our study reveals the potential of producing high-quality dendrochronological data in southern Florida from slash pine, which should prove useful in further studies on fire history and tree phenology and for assessing the projected impacts of impending climate change on the fragile pine rockland community.
\end{abstract}

Keywords: Dendrochronology, Pinus elliottii, slash pine, Florida, response-function analysis, pine rocklands.

\section{INTRODUCTION}

The science of dendrochronology relies on precision during the tree-ring dating process to ensure that each growth ring is correctly assigned to the exact calendar year in which it formed (Douglass 1934, 1941). This required precision creates challenges when working in tropical and subtropical regions. Most studies that involve dendrochronology are conducted in temperate regions, where the majority of tree species produce a single and explicit growth ring each year (Fritts 1976; Speer 2010). Unfortunately, many species located in tropical and subtropical regions do not experience strong seasonality in temperature or precipitation that can cause tree growth to shut

\footnotetext{
*Corresponding author: gharley@utk.edu; Telephone 865-974-2952; Fax 865-974-6025
}

down so that a well-defined ring is formed. However, recent studies show that certain tree species located in these regions produce annual rings (Speer et al. 2004; Brienen and Zuidema 2006; Buckley et al. 2007a; Baker et al. 2008). Tree-ring records from the tropics and subtropics are important because the tropics are relatively underrepresented by proxy data that can be used to infer many broad-scale climate phenomena in the past (e.g. El Niño-Southern Oscillation; D'Arrigo et al. 2006). These tree-ring data provide rare opportunities for understanding the ecological dynamics of tropical and subtropical communities (Brienen et al. 2009).

Pine rockland communities are considered globally endangered because $98 \%$ of these communities have been lost worldwide by land-use conversion and ecological degradation (Noss et al. 
1995). In the United States, pine rockland communities are unique to three areas in southern Florida: Everglades National Park, Big Cypress National Preserve, and the Lower Florida Keys (Snyder et al. 1990). South Florida slash pine (Pinus elliottii Engelm. var. densa Little and Dorman) is the dominant woody species and sole canopy tree in pine rocklands of the Lower Florida Keys. These communities support a diverse subcanopy of West Indian hardwoods and palms, and a variety of endemic herbs that are alternately encouraged or held back by fire (Noss et al. 1995; Sah et al. 2004). Pine rocklands once covered a vast contiguous area of southern Florida of over 75,000 ha, but fire suppression and urbanization during the 20th Century have fragmented and reduced the original range by $90 \%$ (Doren et al. 1993; O'Brien 1998).

Slash pine is the foundation species in pine rockland communities. This species is the southernmost native pine in the United States (Little and Dorman 1954). In the Lower Florida Keys, pine rocklands provide an important habitat for several federal and state listed endangered animal and plant species, including the Key deer (Odocoileus virginianus clavium Barbour \& Allen), the Lower Keys marsh rabbit (Sylvilagus palustris hefneri Lazell), Kirtland's warbler (Dendroica kirtlandii Baird), Garber's spurge (Chamaesyce garberi (Engelm. ex Chapm.) Small), tiny polygala (Polygala smallii R.R. Sm. \& Ward), the Big Pine Key ringneck snake (Diadophis punctatus acricus Paulson), the Florida atala butterfly (Eumaeus atala Röber), and the Florida leafwing butterfly (Anaea troglodyta floridalis Johnson \& Comstock) (Snyder et al. 1990). Frequent burning maintains the associated vegetation of pine rockland communities and prevents succession to tropical hardwood hammocks.

The objectives of this study were to (1) determine if slash pine at its southern range limit forms anatomically distinct growth rings, (2) establish if these growth rings are consistently annual, (3) verify if crossdating is possible within and among trees, and (4) examine which climatic factors influence slash pine growth in the Lower Florida Keys. Our results aim to provide insights into the potential of using slash pine for future dendrochronological studies in southern Florida, which will serve two primary purposes. First, can south Florida slash pine provide useful information on past climate in subtropical locations? Our study reveals which climate variables (such as mean monthly temperature, total monthly precipitation, Atlantic Multidecadal Oscillation (AMO), and El Niño-Southern Oscillation (ENSO)) are important for growth of slash pine. Any statistically significant relationships between climate and pine growth offer the potential for climate reconstruction in a subtropical location. Second, can slash pine yield important information on past fire activity via treering-based fire-scar analyses, similar to studies conducted in locations farther north and west in the U.S.? Slash pine is a fire-adapted species and we have discovered hundreds of fire-scarred pines that could provide valuable information on the range of historical variation in fire regimes of the Lower Florida Keys. Should slash pine prove to be a dendrochronologically viable species, reconstructions of fire history would complement ongoing studies on the role of fire in pine rockland ecosystems (Sah et al. 2010).

\section{PREVIOUS RESEARCH ON SOUTH FLORIDA SLASH PINE}

Southern Florida remains a substantially under-represented area for dendrochronological research because of the difficulty of finding species with annual growth rings. Langdon (1963) first attempted to study the growth patterns of slash pine and installed dendrometer bands on 10 mature trees in the Corkscrew Experimental Forest near Naples, Florida $\left(26.4^{\circ} \mathrm{N}, 81.6^{\circ} \mathrm{W}\right)$ and measured incremental radial growth during the period 1956-1959. Langdon also monitored groundwater level and soil moisture, and compared radial growth to environmental conditions. Langdon found that the first spring flush of growth occurred in early February, and 37\% of the annual growth occurred from February to April, 35\% from May to August, 25\% from September to November, and 3\% from December to January. Diameter growth had two peaks, one in spring centered on March and another in the fall centered on September. Langdon found that 
the 10-month-long growing season (February to November) contributed to a high percentage of latewood and therefore high wood density (the specific gravity of south Florida slash pine is 0.845 (Olson 1952), the highest of all pine species in the U.S. (Forest Products Laboratory 1974)). He further discovered that the lack of moisture during drought conditions in 1956 did not affect radial growth considerably, which he attributed to the fact that the wilting point was not reached in the lower soil depths where moisture was still available to trees. Although his study did not specifically correlate radial growth with climate factors, Langdon (1963) was the first to present a basic understanding of the slash pine growing season in south Florida.

Tomlinson and Craighead (1972) made observations of wood anatomy of several tree species found in southern Florida. They speculated that several species form annual growth rings, including slash pine, which they mentioned as the clearest example of annual growth rings of any species observed. They also noted that the high proportion of latewood to earlywood might be a result of the long growing season that slash pine experiences. Using the results of Langdon (1963) and their own observations, they speculated that the annual reactivation of the cambium corresponds with the first flush of growth during February, at which time the male and female strobili expand. Neither Langdon (1963) nor Tomlinson and Craighead (1972), however, offered any evidence (e.g. ring counts between known stand-wide events) to demonstrate that growth rings in this species are annual, which cannot be assumed given its subtropical location.

Specimens of slash pine in Myakka River State Park, Florida $\left(27.2^{\circ} \mathrm{N}, 82.3^{\circ} \mathrm{W}\right)$ were successfully crossdated by Ford and Brooks (2002) and used to investigate whether increased levels of the Myakka River, caused by damming, amplified forest stress and decline. Their primary objective was to determine the relationship between historical and present river levels and growth of actively managed forested stands located above and below a dam located within the park. Curiously, tree growth and river levels were positively correlated before and after flow increased, suggesting that increased river levels may indirectly cause stress and mortality through increased competition in wet-mesic pine flatwoods. In forested wetland stands, however, Ford and Brooks concluded that increased river levels were the direct cause of extensive mortality upstream from the dam.

Additionally, Ford and Brooks (2003) used tree-ring analyses on slash pine to examine the relationship between radial growth, precipitation minus potential evapotranspiration (P-PET, indicating water availability during times of high demand), and runoff ( $R$, indicating access to groundwater) along a hydrologic gradient at Myakka River State Park. The oldest individual pine established in 1888 , but most individuals established in the early decades of active fire suppression ( $c a .1930$ to 1950). The common period of their three slash pine chronologies spanned 1936-1997 and had interseries correlations of $0.45(\mathrm{n}=7), 0.56(\mathrm{n}=13)$, and $0.57(\mathrm{n}=$ 18), indicating response within each site to a common climate signal. Tree growth was significantly correlated with current year's spring $\mathrm{R}$ and with the current year's spring, summer, and fall PPET at all three sites.

\section{MATERIALS AND METHODS}

\section{Study Area}

Big Pine Key $\left(24.6^{\circ} \mathrm{N}, 81.3^{\circ} \mathrm{W}\right)$ is the largest of the islands that make up the Lower Florida Keys, and contains the most extensive area of contiguous pine rockland and slash pine habitat (920 ha; Figure 1). The pine rocklands on Big Pine Key are located within the National Key Deer Refuge (NKDR), which is managed by the United States Fish and Wildlife Service (USFWS). The tropical savanna climate of the Lower Florida Keys is characterized by hot summers (average maximum August temperature $32.8^{\circ} \mathrm{C}$ ), cool winters (average minimum January temperature $19.4^{\circ} \mathrm{C}$ ), and a distinct summer-wet, winter-dry seasonality. The average annual precipitation is $980 \mathrm{~mm}$, with 80\% occurring from May to November (NOAA 2010; Figure 2). On the rocklands, soil is thin to non-existent and Pleistoceneaged Miami limestone is exposed at the surface (Snyder et al. 1990). 


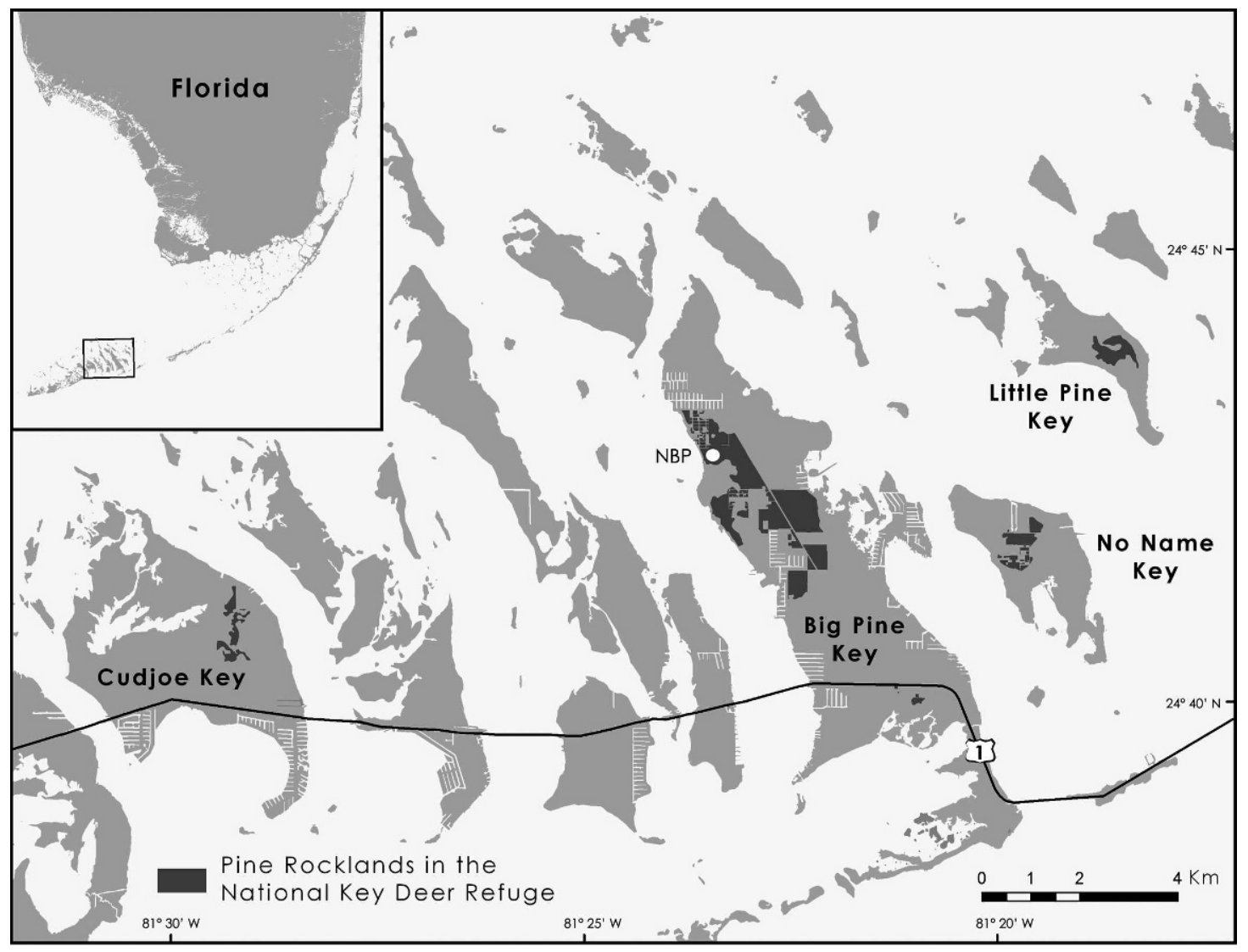

Figure 1. Map showing the location of the NBP site on Big Pine Key and the current distribution of pine rocklands in the National Key Deer Refuge, Lower Florida Keys.

\section{Sampling Design}

To assess the potential of slash pine for dendrochronological research, we conducted a

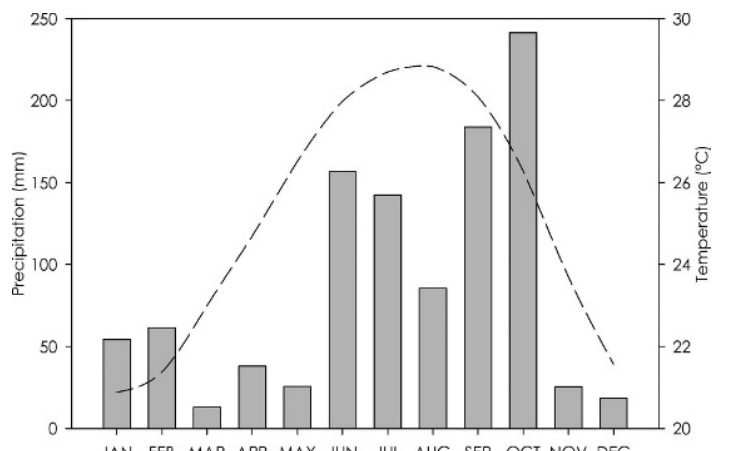

Figure 2. Monthly mean temperature (line) and monthly total precipitation (bars) for Florida Climate Division 7 for the period 1895-2009. specific sampling design aimed at first determining whether trees on Big Pine Key produce a single and explicit growth ring each year. In August 2009, 36 fire-scarred cross-sections from dead and living slash pine trees were collected from a prescribed burn site on North Big Pine Key. The North Big Pine (NBP) site is located on a 25-ha tract of land that last burned on 30 September 1988. According to Bergh and Wisby (1996), this burn was a high-intensity prescribed burn. To determine if slash pine produces a single growth ring each year, we extracted partial sections from dead fire-scarred trees that experienced mortality caused by the 2005 storm surge of Hurricane Wilma and subsequent saltwater impoundment in low-lying areas of the key. The outermost growth ring for these hurricane-killed pines should coincide with the calendar year 2006 or 2007. The variability in outermost ring dates occurs because 
flooding effects from the storm surge (depth and duration) were variable across the island. To test the annual nature of growth rings, a ring count was first conducted with a microscope on samples from the most recent fire scar (1988) to the outermost ring (2006 or 2007).

A second sampling effort in March 2010 focused on developing a long slash pine chronology for comparison with regional climate variables. A total of 60 slash pine core samples (from 23 trees) were collected from NBP. The cores were taken with a 5.15-mm-diameter Haglof increment borer, with 2-4 radii extracted from each tree. Because of the Hurricane Wilma storm surge in 2005, only 23 living trees existed at NBP, all of which had no visible fire injuries. Four radii were necessary on larger trees because the growth rings of older slash pine display poor circuit uniformity. Tree diameters at breast height ranged from 11.7 to $31.5 \mathrm{~cm}$, and increment cores were extracted at $30 \mathrm{~cm}$ above ground level.

\section{Laboratory Methods}

Cores and cross-sections were dried then mounted (Stokes and Smiley 1996), then sanded using progressively finer sandpaper, beginning with ANSI 100-grit (125-149 $\mu \mathrm{m})$ and ending with ANSI 400-grit (20.6-23.6 $\mu \mathrm{m}$ ) (Orvis and Grissino-Mayer 2002). The NBP samples were scanned with a highresolution digital scanner (EPSON, Expression $10000 \mathrm{XL}$ ) at 1,200 dpi and measured and visually crossdated using the WinDENDRO ${ }^{\mathrm{TM}}$ system (version 2009C, Canada). Visual crossdating was confirmed statistically with COFECHA (Holmes 1983; Grissino-Mayer 2001). We used the computer program ARSTAN to standardize tree-ring series to remove the age trend and to minimize effects of autocorrelation in the time series (Cook 1985). Each tree-ring series was detrended with fitted negative exponential curves. Three types of index chronologies were created using the program ARSTAN: standard, residual, and ARSTAN. To determine which chronology best suited our study, we conducted a preliminary correlation analysis between climatic variables (monthly temperature and precipitation from Florida Climate Division 7) and each index chronology. All three index chronologies returned similar results such that the interpretation of the influences of regional climate on tree growth was the same for all chronologies (Gou et al. 2007). The ARSTAN (ARS) chronology, however, showed the highest correlations between tree growth and climatic variables and therefore was used in all further analyses.

\section{Influences of Regional Climate on Tree Growth}

To assess the relationship between climate and radial growth of slash pine, we compared the NBP chronology to regional climate data. National Oceanic and Atmospheric Administration (NOAA) divisional data average observations from all climate stations within each division of a state and assigns equal weight to each station so that divisional data reduce the effects of micro-site climate variation. We selected monthly mean temperature and monthly total precipitation as variables for analysis. Temperature and precipitation data were obtained for the period 1895-2009 from the National Climatic Data Center (NOAA 2010) for Florida Climate Division 7, which includes the southernmost portion of the peninsula.

Broad-scale atmospheric and oceanic oscillations (such as the El Niño-Southern Oscillation (ENSO) and Atlantic Multidecadal Oscillation (AMO)) can have an effect on the climate of south Florida (Ropelewski and Halpert 1986, 1996; Enfield et al. 2001; Schmidt et al. 2001; Beckage et al. 2003; Laing et al. 2008). ENSO cycles are characterized by alternating periods of warm (El Niño) and cold (La Niña) sea surface temperatures in the central and eastern Pacific and occur with a periodicity of three to seven years (Tudhope et al. 2001). In general, winters in the southeastern United States are cooler and wetter during El Niño periods and warmer and drier during La Niña periods (Ropelewski and Halpert 1986, 1996).

However, because of the latitudinal extent of Florida, the southernmost regions and the rest of the state experience different effects of ENSO (Ropelewski and Halpert 1986, 1996; Laing et al. 2008). In the Everglades of south Florida, Beckage et al. (2003) found that the La Niña phase was 
correlated with increased winter precipitation and surface water levels. In contrast, the El Niño phase was associated with decreased winter precipitation and surface water levels.

The AMO is a $65-80$ year cycle of changes in sea-surface temperature anomalies (SSTAs) in the North Atlantic Ocean (Gray et al. 2004). This oscillation is characterized by alternating warm and cool phases, each lasting 20-40 years. Warm AMO phases generally coincide with increased precipitation in Florida and decreased precipitation in the rest of the continental United States. Cool AMO phases correspond with decreased precipitation (drought conditions) in Florida and increased precipitation elsewhere in the US (Enfield et al. 2001).

To determine the effects that ENSO and AMO cycles may have on tree growth in the Lower Florida Keys, we compared the NBP chronology with (1) ENSO: mean monthly SSTAs from the Niño-3.4 Region, east central Tropical Pacific $\left(5^{\circ} \mathrm{N}-5^{\circ} \mathrm{S}, \quad 170-120^{\circ} \mathrm{W}\right)$, available from 1871 to 2007 (Trenberth and Stephaniak 2000); and (2) AMO: North Atlantic SSTAs, based on a $5^{\circ}$ latitude by $5^{\circ}$ longitude global SST grid, unsmoothed, available from 1856 to 2009 (Kaplan et al. 1998).

\section{Response Function and Correlation Analysis}

We used response-function (RFA) and correlation analysis to examine how regional climatic variables (monthly mean temperature and monthly total precipitation) influence radial growth of slash pine (Fritts et al. 1971; Fritts and Xiangding 1986). RFA is a multiple regression technique that estimates indexed values of ring-width using the principal components of monthly climatic data. Correlation analysis produced coefficients that were univariate estimates of Pearson's productmoment correlation (Biondi and Waikul 2004). Similar to the response functions, correlation coefficients were calculated with bootstrapped confidence intervals to reduce potential error and obtain more accurate results (Biondi 1997).

We conducted these analyses using climate variables covering a 23-month period (February of the previous year to December of the current year of radial growth). This period was selected because conditions during the previous- and current-year growing season can affect the amount of carbon fixed and allocated to tree growth (GrissinoMayer and Butler 1993; Foster and Brooks 2001). Response-function and correlation coefficients were produced using the program DENDROCLIM2002, which uses bootstrapping to yield more accurate confidence levels (Biondi 1997; Biondi and Waikul 2004). Coefficients that equaled or exceeded the $95 \%$ confidence level were identified by the program. To determine the influence that cycles of ENSO and AMO have on tree growth, correlation coefficients were produced using DENDROCLIM2002.

\section{RESULTS}

\section{Growth Ring Anatomy of Slash Pine}

In the Lower Florida Keys, slash pine forms anatomically distinct growth rings (Figure 3 ). The growth-ring boundaries contain tracheid cells that have thicker cell walls and smaller cell lumens, similar to the latewood cells of the other southern yellow pines (e.g. Pinus elliottii Engelm. var. elliottii, Pinus palustris Mill., Pinus echinata Mill., Pinus taeda L.). The latewood zone in growth rings occurs when earlywood cells with thin cell walls rapidly change into latewood cells with thick cell walls. Often, variations in cell dimensions within annual growth rings, generally in the later portions of earlywood zones, occur in which a thin band of tracheid cells with thicker cell walls forms. These variations are numerous and give the appearance of a false ring, but these were easily identified by the gradual transition from latewood to earlywood cells (Speer 2010).

\section{Annual-Ring Assessment and Chronology Development}

Samples from NBP demonstrate that the anatomically distinct growth rings formed by slash pine are annual. First, our ring counts on samples that contain the 1988 fire scar and then experienced mortality shortly after the 2005 Hurricane Wilma storm surge reveal that these individuals formed a single and explicit growth ring each year 


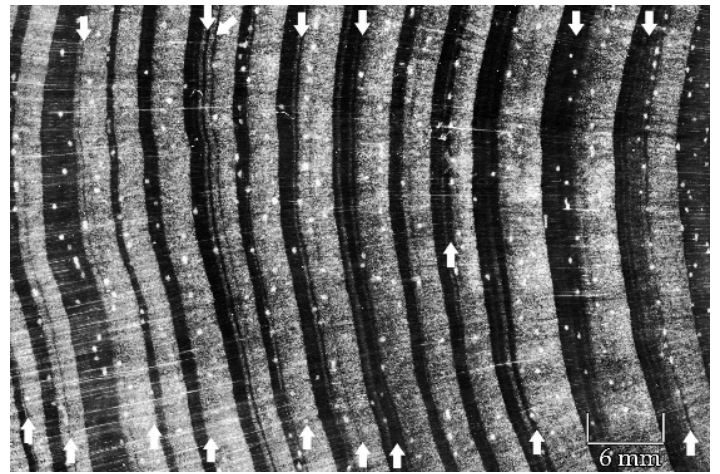

Figure 3. Annual growth rings in slash pine (cross-section). In many growth rings, a false ring occurred in the late portion of earlywood growth (shown by arrows).

from 1988 to 2006/2007 (Table 1). Furthermore, we were able to successfully crossdate tree rings from both increment cores and sections from NBP and develop a tree-ring chronology for this site (Figure 4). Of the 60 slash pine tree cores that were collected, 24 cores from eight trees could not be crossdated with the master chronology $(60 \%$ success rate). Fifteen of the 36 fire-scarred crosssections collected from NBP were crossdated against the master chronology, although this process is ongoing and we expect to eventually crossdate tree rings from most cross-sections. The 53 dated series (from 31 trees) from NBP produced a 139-year chronology (1871-2009) with a high interseries correlation (0.52) and mean sensitivity (0.39), and only 13 segments were

Table 1. Ring count results for NBP samples from the most recent fire date at the site (1988; Bergh and Wisby 1996) to the tree death date (2006 or 2007; Morkill 2009).

\begin{tabular}{lccc}
\hline Sample ID & $\begin{array}{c}\text { Most Recent } \\
\text { Fire Date }\end{array}$ & $\begin{array}{c}\text { Outermost } \\
\text { Ring }\end{array}$ & $\begin{array}{c}\text { \# Rings Between } \\
\text { Fire Scar and } \\
\text { Outermost Ring }\end{array}$ \\
\hline NBP501 & 1988 & 2006 & 18 \\
NBP503 & 1988 & 2007 & 19 \\
NBP514 & 1988 & 2006 & 18 \\
NBP515 & 1988 & 2006 & 18 \\
NBP516 & 1988 & 2006 & 18 \\
NBP531 & 1988 & 2007 & 19 \\
NBP534 & 1988 & 2006 & 18 \\
NBP538 & 1988 & 2006 & 18 \\
NBP543 & 1988 & 2007 & 19 \\
\hline
\end{tabular}

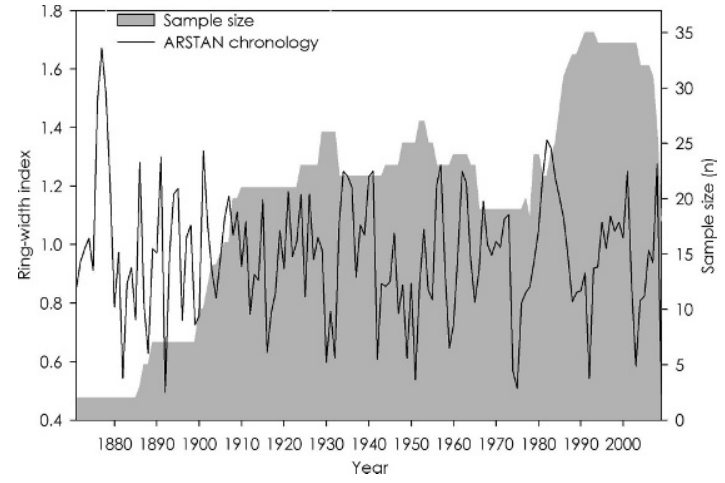

Figure 4. ARSTAN chronology and sample depth for slash pine from the NBP site on Big Pine Key.

flagged by COFECHA as problematic (8\%; Table 2). Among the crossdated trees, five distinct marker years were prominent: 1892, 1916, 1942, 1992, and 2003. All five were $>2$ standard deviations narrower than the mean ring-width value. Overall, most series did not contain locally absent rings, although the 1943 growth ring was missing in several series.

\section{Influence of Climatic Variables on Tree Growth}

The slash pine chronology from NBP correlated with climate data from Florida Climate Division 7, indicating that regional climate influences radial growth. Annual growth of slash pine at NBP is primarily influenced by precipitation

Table 2. Descriptive statistics from COFECHA for NBP (18712009).

\begin{tabular}{lc}
\hline Number of trees & 32 \\
Number of dated series ${ }^{1}$ & 53 \\
Master series time span (yrs) & 139 \\
Total rings & 2,747 \\
Interseries correlation ${ }^{2}$ & 0.520 \\
Mean sensitivity & 0.399 \\
Chronology start date $^{4}$ & 1886 \\
Percent flags ${ }^{5}$ & 12 \\
\hline & \\
& \\
&
\end{tabular}



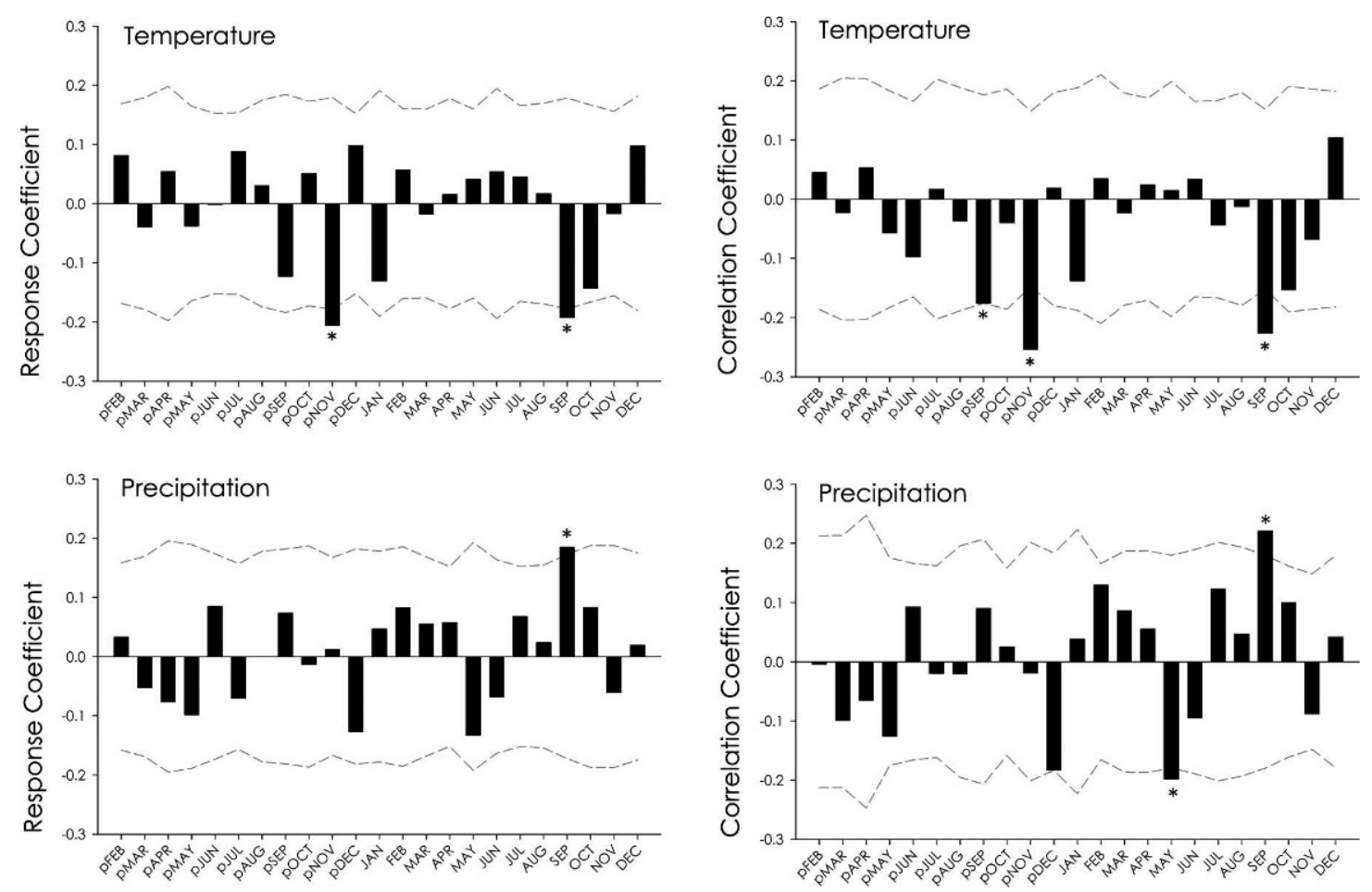

Figure 5. Annual growth response to monthly mean temperature and monthly total precipitation for the NBP chronology from previous February (pFEB) to current December (DEC) for the period 1895-2009. Response coefficients between NBP and climatic variables are shown in the left column and correlation coefficients are shown in the right column. Dashed lines indicate $95 \%$ confidence limits and asterisks indicate statistically significant months.

and available moisture during the growing season. RFA indicated that radial growth at NBP responded positively to current September precipitation and negatively to both previous November and current September temperature (Figure 5).

Correlation analysis between monthly mean temperature and the NBP chronology resulted in significant negative correlations between radial growth and current September and previous September and November temperature (Figure 5). We also found a significant negative correlation with current May precipitation and a significant positive correlation with current September precipitation.

The comparison between the NBP chronology and the Niño 3.4 and AMO indices (not shown) showed a weak response of tree growth to North Atlantic conditions and no relationship with ENSO in slash pine. The NBP chronology is significantly and positively correlated with the
AMO index only during current April, but the association is quite weak $(\mathrm{r}=0.17, \mathrm{p}<0.05)$.

\section{DISCUSSION}

The foundation species slash pine provides an opportunity to investigate the historical variation in regional climate and vegetation dynamics of pine rockland communities in the Lower Florida Keys. The presence of anatomically distinct and annual growth rings, high-quality crossdating (as shown by a high interseries correlation), and statistically significant correlations and RFA coefficients with climate makes slash pine a useful candidate for dendrochronological, ecological, and biogeographical studies in southern Florida. Langdon (1963) and Tomlinson and Craighead (1972) suggested that slash pine forms annual rings, but ours is the first study to confirm the annual nature of its growth rings, assess its 
crossdating potential, develop a chronology, and identify statistically significant relationships between radial growth and climate at its southern range limit.

Although slash pine produces annual rings, crossdating was challenging. False rings were problematic in many samples, as were a few locally absent growth rings. Five cross-sections contained locally absent rings that occurred after the very narrow 1942 growth ring. This suggests that a long-term physiological growth decline in slash pine, ultimately resulting in an absence of xylogenesis during 1943, may have been initiated by adverse environmental conditions the previous year. False rings generally occurred just before the earlywood/latewood transition zone, suggesting that unusually low rainfall during earlywood growth might cause individuals to prematurely form tracheids with thicker cell walls, causing a false ring to appear before the formation of latewood cells.

Response-function and correlation analysis revealed significant relationships between radial growth and precipitation and indicate that annual growth of slash pine at the NBP site is primarily influenced by water availability during the growing season. This corroborates the findings of Ford and Brooks (2003), who found slash pine at its northern range limit in central Florida to be sensitive to water availability during times of high demand. RFA indicated that previous November and current September temperature and current September precipitation are the most important predictors of radial growth at NBP. The response functions between tree growth and climatic variables suggest that warmer temperatures towards the end of the growing season result in less radial growth, likely because of increased moisture stress from higher temperatures. Additionally, increased late-season rainfall during September results in prolonged growth before dormancy occurs, thus producing a wider-than-average growth ring. Significant negative correlations between tree growth and late summer temperatures and May precipitation also support the argument that these relationships are likely a signal of moisture stress, as higher temperatures result in higher rates of evapotranspiration.
We did not find significant relations between tree growth and the Palmer drought indices (Palmer Drought Severity Index (PDSI) and Palmer Hydrological Drought Index (PHDI)). This was not a surprising result for several reasons. First, the closest PDSI grid point to the NBP chronology is located in central Florida $\left(82.5^{\circ} \mathrm{W}, 27.5^{\circ} \mathrm{N}\right.$; Cook et al. 2004). The highly variable weather experienced from mainland Florida southward to the Lower Florida Keys might explain the lack of statistically significant response of slash pine to PDSI and PHDI (Winsberg 2003). Second, the Palmer drought indices are derived from measurements of precipitation, air temperature, and local soil moisture. The poor to non-existent soil development on Big Pine Key might also partly explain the lack of result.

The lack of a statistically significant response of slash pine to AMO was unexpected because the geographic proximity of our site to the influence of this oscillation suggested a significant climate response would be found. Our site is located on a small $\left(25.8 \mathrm{~km}^{2}\right)$ island. Surrounded by vast expanses of ocean (tropical Atlantic to the east and Gulf of Mexico to the west), trees at the NBP site were strong candidates for picking up a signal from the North Atlantic ocean-atmospheric oscillations. Warm phases of the AMO correspond with increased precipitation and increased landfalling tropical storms in southern Florida. However, the response likely was instead manifest in the positive correlation and RFA coefficients found with September precipitation. On the other hand, ENSO SSTAs usually reach their peak and maximum aerial extent in the tropical Pacific during the winter months (Laing et al. 2008). Our RFA indicated that winter precipitation (December-February) is not an important component of annual tree growth, so the lack of an ENSO signal in the NBP pines is understandable.

Interpreting relationships between regional climate and tree growth at the NBP site, however, is limited by the lack of detailed information regarding the phenological properties of slash pine, such as when cambial reactivation, earlywood growth, latewood growth, and dormancy occur, and which environmental factors cause 
these changes in xylogenesis. These data are needed before more detailed interpretations of climate-tree growth relationships can be made. Consequently, we have initiated a long-term study on Big Pine Key aimed at providing detailed phenological data that will help further define the length of the growing season and determine which climate factors cause slash pine to form false and locally absent growth rings. This study will examine growth of six pines on a biweekly to monthly basis by extracting and preserving small punch cores and observing the amount and types of cells produced between intervals.

\section{CONCLUSIONS}

Tree-ring analysis in Florida has primarily been limited to species located in central-northern regions of the state (Foster and Brooks 2001; Ford and Brooks 2002, 2003; Henderson and GrissinoMayer 2009). The majority of tree species in south Florida fail to produce annual rings (Tomlinson and Craighead 1972), yet our research demonstrates that slash pine is a species of dendrochronological value. Multidecadal, and possibly multicentennial, chronologies can be developed and used to provide more detailed information regarding the structure and dynamics of endangered pine rockland communities and how disturbance regimes (e.g. hurricanes and wildfires) have shaped the current distribution of slash pine in the Lower Florida Keys. Furthermore, slash pine is the southernmost pine species in the United States and the only pine to inhabit the lower third of peninsular Florida (Little and Dorman 1954). Because slash pine in the Lower Florida Keys exists at its southern range limit, the species could prove vital for understanding the possible effects of future climate change on range distributions of species in habitats that could be especially vulnerable to increasing global temperatures. The expected higher temperatures could reduce growth rates of these pines as indicated by the correlation and RFA results, leading to moisture stress that could lead to increased mortality of pines that survived the effects of Hurricane Wilma. Warmer temperatures, rising seas levels, and increased incidence of salt-water intrusion may render other studies of slash pine in the Lower Florida Keys impossible, creating the need for a better understanding of pine rockland dynamics while they still exist.

\section{ACKNOWLEDGMENTS}

This research was funded by the United States Fish and Wildlife Service and we thank Anne Morkill, Chad Anderson, and Phillip Hughes for access to the National Key Deer Refuge. We thank John Sakulich and Desiree Kocis for field assistance and Kody Honeyman for laboratory assistance. G.L. Harley was supported by National Science Foundation grant number DGE-0538420.

\section{REFERENCES CITED}

Baker, P., J. Palmer, and R. D’Arrigo, 2008. The dendrochronology of Callitris intratropica in northern Australia: Annual ring structure, chronology development and climate correlations. Australian Journal of Botany 56:311-320.

Beckage, B., W. J. Platt, M. G. Slocum, and B. Panko, 2003. Influence of the El Niño-Southern Oscillation on fire regimes in the Florida Everglades. Ecology 84:3124-3130.

Bergh, C., and J. Wisby, 1996. Fire History of the Lower Keys Pine Rocklands. The Nature Conservancy Special Report, $38 \mathrm{pp}$.

Biondi, F., 1997. Evolutionary and moving response functions in dendroclimatology. Dendrochronologia 15:139-150.

Biondi, F., and K. Waikul, 2004. DENDROCLIM2002: A C++ program for statistical calibration of climate signals in treering chronologies. Computers \& Geosciences 30:303-311.

Brienen, R. J. W., and P. A. Zuidema, 2006. The use of tree rings in tropical forest management: Projecting timber yields of four Bolivian tree species. Forest Ecology and Management 226:256-267.

Buckley, B. M., K. Palakit, K. Duangsathaporn, P. Sanguantham, and P. Prasomsin, 2007. Decadal scale droughts over northwestern Thailand over the past 448 years: Links to the tropical Pacific and Indian Ocean sectors. Climate Dynamics 29:63-71.

Cook, E. R., 1985. A Time Series Analysis Approach to Tree Ring Standardization. Ph.D. dissertation, University of Arizona, Tucson.

Cook, E. R., C. A. Woodhouse, C. M. Eakin, D. M. Meko, and D. W. Stahle, 2004. Long-term aridity changes in the Western United States. Science 306(5698):1015-1018.

D’Arrigo, R. D., R. J. Wilson, J. Palmer, P. J. Krusic, A. Curtis, J. Sakulich, S. Bijaksana, S. Zulaikah, and L. O. Ngkoimani, 2006. Monsoon drought over Java, Indonesia, during the past two centuries. Geophysical Research Letters 33:L04709. doi:10.1029/2005GL025465. 
Doren, R. F., W. J. Platt, and L. D. Whiteaker, 1993. Density and size structure of pine stands in the everglades region of south Florida. Forest Ecology and Management 59:295-311.

Douglass, A. E., 1934. Editorial. Tree-Ring Bulletin 1:2-3.

Douglass, A. E., 1941. Notes on the technique of tree-ring analysis, II: Cell illumination. Tree-Ring Bulletin 7:28-34.

Enfield, D. B., A. M. Mestas-Nuñez, and P. J. Trimble, 2001. The Atlantic Multidecadal oscillation and its relation to rainfall and river flows in the continental U.S. Geophysical Research Letters 28:2077-2080.

Ford, C. R., and J. R. Brooks, 2002. Detecting forest stress and decline in response to increasing river flow in southwest Florida, USA. Forest Ecology and Management 160:45-64.

Ford, C. R., and J. R. Brooks, 2003. Hydrological and climatic responses of Pinus elliottii var. densa in mesic pine flatwoods Florida, USA. Annals of Forest Science 60:385-392.

Forest Products Laboratory, 1974. Wood Handbook: Wood as an Engineering Material. USDA Forest Service. Agricultural Handbook 72.

Foster, T. E., and J. R. Brooks, 2001. Long-term trends in growth of Pinus palustris and Pinus elliottii along a hydrological gradient in central Florida. Canadian Journal of Forest Research 31:1661-1670.

Fritts, H. C., 1976. Tree Rings and Climate. Academic Press, New York.

Fritts, H. C., and W. Xiangding, 1986. A comparison between response-function analysis and other regression techniques. Tree-Ring Bulletin 46:31-46.

Fritts, H. C., T. J. Blasing, B. P. Hayden, and J. E. Kutzbach, 1971. Multivariate techniques for specifying tree-growth and climate relationships and for reconstructing anomalies in paleoclimate. Journal of Applied Meteorology 10:845-864.

Gou, X., F. Chen, G. Jacoby, E. R. Cook, M. Yang, J. Peng, and Y. Zhang, 2007. Rapid tree growth with respect to the last 400 years in response to climate warming, northeastern Tibetan Plateau. International Journal of Climatology 27: 1497-1503.

Gray, S. T., L. J. Graumlich, J. L. Betancourt, and G. T. Pederson, 2004. A tree-ring based reconstruction of the Atlantic Multidecadal Oscillation since 1567 A.D. Geophysical Research Letters 31:L12205. doi:10.1029/2004GL019932.

Grissino-Mayer, H. D., 2001. Evaluating crossdating accuracy: A manual for the program COFECHA. Tree-Ring Research 57:205-219.

Grissino-Mayer, H. D., and D. R. Butler, 1993. Effects of climate on growth of shortleaf pine (Pinus echinata Mill.) in northern Georgia: A dendroclimatic study. Southeastern Geographer 33:65-81.

Henderson, J. P., and H. D. Grissino-Mayer, 2009. Climate-tree growth relationships of longleaf pine (Pinus palustris Mill.) in the southeastern Coastal Plain, USA. Dendrochronologia 27: $31-43$.

Holmes, R. L., 1983. Computer-assisted quality control in treering dating and measurement. Tree-Ring Bulletin 43:69-78.

Kaplan, A., M. Cane, Y. Kushnir, A. Clement, M. Blumenthal, and B. Rajagopalan, 1998. Analyses of global sea surface temperature 1856-1991. Journal of Geophysical Research 103: 18567-18589.
Langdon, O. G., 1963. Growth patterns of Pinus elliottii var. densa. Ecology 44:825-827.

Laing, A., M. LaJoie, S. Reader, and K. Pfeiffer, 2008. The influence of the El Niño-Southern Oscillation on cloud-toground lightning activity along the Gulf Coast. Part II: Monthly Correlations. Monthly Weather Review 136: 2544-2556

Little, E. L., and K. W. Dorman, 1954. Slash Pine (Pinus elliottii), including South Florida Slash Pine, Nomenclature and Description. U.S. Forest Service Southeast Forest Experimental Station Paper 36, 82 pp.

National Oceanic and Atmospheric Administration (NOAA), 2010. Website: www. ncdc.noaa.gov/oa/ncdc.html. National Climatic Data Center, US Department of Commerce. Accessed 15 March 2010.

Noss, R. F., E. T. LaRoe, and J. M. Scott, 1995. Endangered Ecosystems of the United States: A Preliminary Assessment of Loss and Degradation. U.S. Department of the Interior, Biological Report 28, Washington D.C.

O'Brien, J. J., 1998. The distribution and habitat preferences of rare Galactia species (Fabaceae) and Chamaesyce deltoidea subspecies (Euphorbiaceae) native to southern Florida pine rockland. Natural Areas Journal 18:209-222.

Olson, D. F., Jr., 1952. Regeneration of South Florida Slash Pine is Subject of New Research. U.S. Forest Service, Southeastern Forest Experiment Station, Research Note 18.

Orvis, K. H., and H. D. Grissino-Mayer, 2002. Standardizing the reporting of abrasive papers used to surface tree-ring samples. Tree-Ring Research 58:47-50.

Palmer, W. C., 1965. Meteorological Drought. U.S. Weather Bureau Research Paper No. 45.

Ropelewski, C. F., and M. S. Halpert, 1986. North American precipitation and temperature patterns associated with the El Niño Southern Oscillation (ENSO). Monthly Weather Review 114:2352-2362.

Ropelewski, C. F., and M. S. Halpert, 1996. Quantifying Southern Oscillation-precipitation relationships. Journal of Climate 9:1043-1059.

Sah, J. P., M. S. Ross, S. Koptur, and J. R. Snyder, 2004. Estimating aboveground biomass of broadleaved woody plants in the understory of Florida Keys pine forests. Forest Ecology and Management 203:319-329.

Sah, J. P., M. S. Ross, J. R. Snyder, and D. E. Ogurcak, 2010. Tree mortality following prescribed fire and a storm surge event in slash pine (Pinus elliottii var. densa) forests in the Florida Keys, USA. International Journal of Forestry Research. Art. 204795, doi:10.1155/2010/204795.

Schmidt, N., E. K. Lipp, J. B. Rose, and M. E. Luther, 2001. ENSO influences on seasonal rainfall and river discharge in Florida. Journal of Climate 14:614-628.

Snyder, J. R., A. Herndon, and W. B. Robertson, Jr., 1990. South Florida Rocklands. In Ecosystems of Florida, edited by R. L. Myers, and J. J. Ewel, pp. 230-277. University of Central Florida Press, Orlando, Florida.

Speer, J. H., 2010. Fundamentals of Tree-Ring Research. University of Arizona Press, Tucson.

Speer, J. H., K. H. Orvis, H. D. Grissino-Mayer, L. M. Kennedy, and S. P. Horn, 2004. Assessing the dendrochron- 
ological potential of Pinus occidentalis Swartz in the Cordillera Central of the Dominican Republic. The Holocene 14:563-569.

Stokes, M. A., and T. L. Smiley, 1996. An Introduction to TreeRing Dating. University of Arizona Press, Tucson, Arizona (originally pub. 1968 by U. of Chicago Press).

Tomlinson, P. B., and F. C. Craighead, 1972. Growth ring studies on the native trees of subtropical Florida. In Research Trends in Plant Anatomy, edited by A. K. M. Ghouse, and M. Yunus, pp. 39-51. Tata McGraw-Hill, Bombay.

Trenberth, K. E., and D. P. Stephaniak, 2000. Indices of the El Niño evolution. Journal of Climate 14:1697-1701.
Tudhope, A. W., C. P. Chilcott, M. T. McCulloch, E. R. Cook, J. Chappell, R. M. Ellam, D. W. Lea, J. M. Lough, and G. B. Shimmield, 2001. Variability in the El Nino-Southern Oscillation through a glacial-interglacial cycle. Science 291: $1511-1517$.

Winsberg, M. D., 2003. Florida Weather. University Press of Florida, Gainesville, Florida.

Received 21 June 2010; accepted 10 October 2010. 